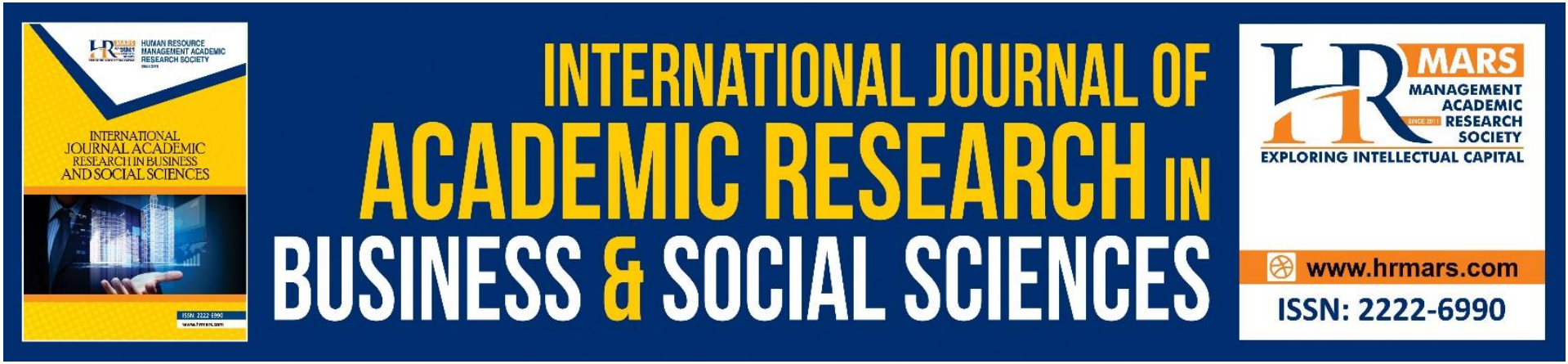

\title{
Impact of Dividend Policy on Share Price of Listed Ict Firms in Nigeria
}

Omaliko Emeka L., Onyeogubalu Ogochukwu. N

To Link this Article: http://dx.doi.org/10.6007/IJARBSS/v11-i9/8937

DOI:10.6007/IJARBSS/v11-i9/8937

Received: 02 July 2021, Revised: 27 July 2021, Accepted: 20 August 2021

Published Online: 23 September 2021

In-Text Citation: (Emeka \& Ogochukwu, 2021)

To Cite this Article: Emeka, O. L., \& Ogochukwu, O. N. (2021). Impact of Dividend Policy on Share Price of Listed Ict Firms in Nigeria. International Journal of Academic Research in Business and Social Sciences, 11(9), 14891502.

\section{Copyright: (c) 2021 The Author(s)}

Published by Human Resource Management Academic Research Society (www.hrmars.com)

This article is published under the Creative Commons Attribution (CC BY 4.0) license. Anyone may reproduce, distribute, translate and create derivative works of this article (for both commercial and non-commercial purposes), subject to full attribution to the original publication and authors. The full terms of this license may be seen at: http://creativecommons.org/licences/by/4.0/legalcode

Vol. 11, No. 9, 2021, Pg. 1489 - 1502

Full Terms \& Conditions of access and use can be found at http://hrmars.com/index.php/pages/detail/publication-ethics 


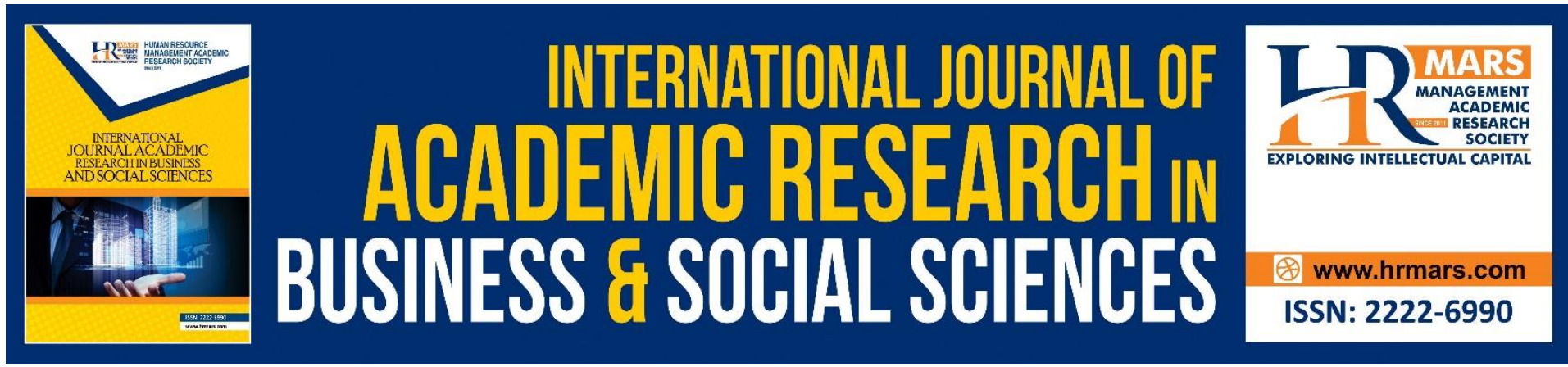

\title{
Impact of Dividend Policy on Share Price of Listed Ict Firms in Nigeria
}

\author{
Omaliko Emeka L. Ph.D \\ Department of Accountancy, Faculty of Management Sciences, Nnamdi Azikiwe University, \\ P.M.B. 5025 Awka, Anambra State, Nigeria. \\ Email: el.omaliko@unizik.edu.ng

\section{Onyeogubalu Ogochukwu. N} \\ Department of Accountancy, Faculty of Management Sciences, Nnamdi Azikiwe University, \\ P.M.B. 5025 Awka, Anambra State, Nigeria. \\ Email: on.onyeogubalu@unizik.edu.ng
}

\begin{abstract}
This study empirically investigated the impact of Dividend Policy on Share Price of Firms Listed on ICT Sector of Nigerian Stock Exchange. In order to determine the relationship between dividend policy and share price of firms, dividend policy key proxy variables were used in the study, namely; Dividend Payout (DPO), Dividend Per Share (DPS) and Dividend Yield (DY) while Share Price (SP) on the other hand was measured using Market Price of Shares (MPS). Three hypotheses were formulated to guide the investigation and the statistical test of parameter estimates was conducted using OLS Model operated with STATA 15. Ex Post Facto Design was adopted and data for the study were obtained from the Nigerian Stock Exchange Factbook and Annual Reports and Accounts of listed ICT firms in Nigeria spanning from 2016-2020. The findings generally indicate that Dividend Payout, Dividend Per Share \& Dividend Yield have exerted significant and positive impact on Firms Share Price at $1 \%$ significant level. Based on this, the study concludes that dividend policy is capable of influencing firms' share prices in Nigeria. By this implication, the study supports the relevant theories of dividend policy reviewed in this study as irrelevant theories of dividends do not hold in the case of Nigeria. The study recommends among others that firms' willing to maximize share price should consistently increase their dividend payment as this sends signal to the investors about the firm's market performance and financial health.
\end{abstract}

Keywords: Dividend Policy, Dividend Yield, Dividend Per Share, Dividend Payout, Share Price

\section{Introduction}

Dividend policy has remained one of the controversial issues in corporate finance. Ordu, Enekwe and Anyanwaokoro (2014) noted that some financial analysts attribute the failure of some quoted firms to non-payment of dividends which according to them made investors lose interest in trading on stocks. Investors are by nature risk averse, and the volatility of their investments is of importance to them because it is a measure of the level of risk they are 
exposed to. Investors will naturally invest in stock with forecasted positive return on investment and a dividend policy that encourages higher dividend payout. In line with Ordu, Enekwe, and Anyanwaokoro's perspective, the objective of the firm is the maximization of shareholders wealth and once investors don't get the value of their investment, they tend to divert their funds to other investment opportunities that could yield them immediate returns. The study also posit that dividend payment is a major component of stock return to shareholders which provides signal to investors that the company is complying with good corporate governance practices.

From the a priori expectations, it was observed that corporate organisations are faced with the problem of whether to pay a large, small or zero percentage of their earnings as dividend vis-à-vis financing future investment projects. This problem is borne out of the desire to satisfy the various needs of shareholders. Some shareholders have the need for income now and as such will prefer a high dividend payout ratio, while others who need to invest for the future would prefer capital gains. Due to the fact of having to deal with competing interests of various shareholders, the kind of dividend policy a firm adopts could either lead to positive or negative effects on the share prices of the company. The managers are therefore unable to forecast with certainty to what extent the policy will affect the market price of shares of their firm (Okafor, Mgbame, \& Chijioke-Mgbame, 2011).

Research in dividend policy and firms earnings have shown not only that a general theory of dividend policy remains elusive, but also that corporate dividend practice varies over time among firms and across countries. The pattern of corporate dividend policies does not only vary over time but also across countries, especially between developed and emerging financial institutions. However a large number of firms in the developing economies are still apathetic about their dividend decisions as they are unaware of the connection between the dividend decisions and their performance. Based on this observation, this study considered it imperative to examine the relationship between dividend policy and share price of firms.

\section{Statement of Problem}

Dividend decision is one of the most critical decisions in corporate finance. It adds to the shareholders' wealth and to the organizational value. That is the reason numerous studies have been undertaken in this particular area. In Nigeria, there are not sufficient studies available which have investigated the impact of dividend policy on firms share price. Previous researchers have mainly focused on developed countries while for less developed countries like Nigeria, studies have been either conducted to less extent or no extent. And more importantly, there is no known study which had examined the impact of dividend policy on market price of shares with reference to firms quoted under Information and Communication Technology (ICT) Sector in Nigeria. Also some theoretical and empirical literatures have been developed to examine the effect as well as the relationship between the determinants of dividend policy and the market prices of shares but none concentrated on Information and Communication Technology (ICT) Sector of Nigerian Stock Exchange (NSE).

Despite the active theoretical and empirical research, what determines corporate share price in the context of developing nations as regard to firms' dividend policy remains an empirical question in corporate finance. Thus, theory provides conflicting predictions on whether dividend policy determines firms' share price which calls for further investigation and clarifications.

Against these backdrops, this study seeks to examine the impact of dividend policy on share price in ICT Sector of Nigeria. Specifically, the study aims; 
$>$ to examine the impact of Dividend Pay-out on Share Price of Listed ICT Firms in Nigeria.

$>$ to determine the impact of Dividend Yield on Share Price of Listed ICT Firms in Nigeria and

$>$ to ascertain the impact of Dividend Per Share on Share Price of Listed ICT Firms in Nigeria.

In order to direct the direct flow of this study, the following hypotheses were formulated in a null form:

$\mathbf{H}_{01}$ : Dividend Payout has no significant impact on Share Price of Listed ICT Firms in Nigeria.

$\mathrm{H}_{02}$ : Dividend Yield has no significant impact on Share Price of Listed ICT Firms in Nigeria.

$\mathrm{H}_{03}$ : Dividend Per Share has no significant impact on Share Price of Listed ICT Firms in Nigeria.

\section{Review of Related Literature Dividend Policy}

According to Nissim and Ziv, (2011) dividend policy is the regulations and guidelines that a company uses to decide to make dividend payments to shareholders. The dividend policy decisions of firms are the primary element of corporate policy. Dividend, which is basically the benefit of shareholders in return for their risk and investment, is determined by different factors in an organization. Basically, these factors include financing limitations, investment chances and choices, firm size, pressure from shareholders and regulatory regimes.

Olimalade, Ojo and Adewumi (2017) opine that dividend policy is cash flow that accrues to equity investors. That is a form of return to shareholders on their investment, and the aim is to increase their confidence in the future of the company in which they have invested. According to the study, dividend policy is seen as the rationale under which a firm determines what it will pay in dividends. This encompasses both the amount paid and the pattern under which changes in amount occur over time. That is, it entails striking a balance between future growth and payment of current dividends to firm's shareholders.

\section{Determinants of Dividend Policy Dividend Payout}

According to Rehman (2016), dividend payout ratio is often known as a measure of dividend policy, and the most fundamental question is whether or not the dividend should be paid. The study is of the opinion that corporate finance theory is yet to answer this basic question. That is why dividend policy is considered to be a dark area in corporate finance theory. The cash flow position of a firm is an important determinant of dividend payouts. A poor liquidity position means less generous dividend due to shortage of cash (Omaliko \& Okpala, 2020).

Omaliko and Okpala (2020) refer to dividend payout as a decision regarding the magnitude of the dividend payment paid by the firms, the percentage of earnings paid to the stockholders in the form of dividends. It is based on the answers to several important questions such as how much dividend should a company distribute to shareholders? What will the impact of the dividend policy be on the company's share price? What will happen if the amount of dividend changes from year to year? By implication, dividend policy of a firm is very important as it tells a firm when and how to make the payment and the extent of the payment to be made. 


\section{Dividend Yield}

Dividend yield is a financial ratio that measures the amount of cash dividends distributed to common shareholders relative to the market value per share. The dividend yield is used by investors to show how their investment in stock is generating either cash flows in the form of dividends or increases in asset value by stock appreciation (Nissim \& Ziv, 2011).

According to Sorin (2016), dividend yield expressed as a percentage, is a financial ratio that shows how much a company pays out in dividends each year relative to its stock price. The reciprocal of the dividend yield is the dividend payout ratio. The dividend payout ratio is the ratio of the total amount of dividends paid out to shareholders relative to the net income of the company while dividend yield is the financial ratio that measures the cash dividends paid out to shareholders relative to the market value per share.

\section{Dividend Per Share}

This is an amount of dividend a stockholder receives for each share of stock held. It can be calculated by taking the total amount of dividends paid and dividing it by the total shares outstanding. As cited in Ogbuagu (2020), dividend per share (DPS) is the sum of declared dividends issued by a company for every ordinary share outstanding. The figure is calculated by dividing the total dividends paid out by a business, including interim dividends, over a period of time by the number of outstanding ordinary shares issued. DPS is an important metric to investors because the amount a firm pays out in dividends directly translates to income for the shareholder, and the DPS is the most straightforward figure an investor can use to calculate his or her dividend payments from owning shares of a stock over time.

\section{Share Price}

According to Ejuvbekpokpo and Okoro (2014), share prices serve as the basis for the assessment of whether a firm is at break even or not. These prices are relevant metrics of returns to stakeholders, therefore the value attached to them matters so much to both existing and prospective investors in the capital market. According to Omaliko, Nweze and Nwadialor (2020), market price of shares is one of the market based measures suitable for corporate performance assessment.

As noted in the study of Malhotra and Tandon, (2013), share prices dynamics and that is why investors and fund managers have been confronted with the problem of accurately predicting the stock prices so as to earn decent returns. Investment in shares offers the benefit of liquidity as well as the opportunity to beat the market and earn high returns, but the task of predicting share prices is far from simple. Share price movement is not independent in nature and both intrinsic as well as extrinsic factors have been established to exercise influence over stock price movements (Omaliko, Okeke \& Obiora, 2021). 


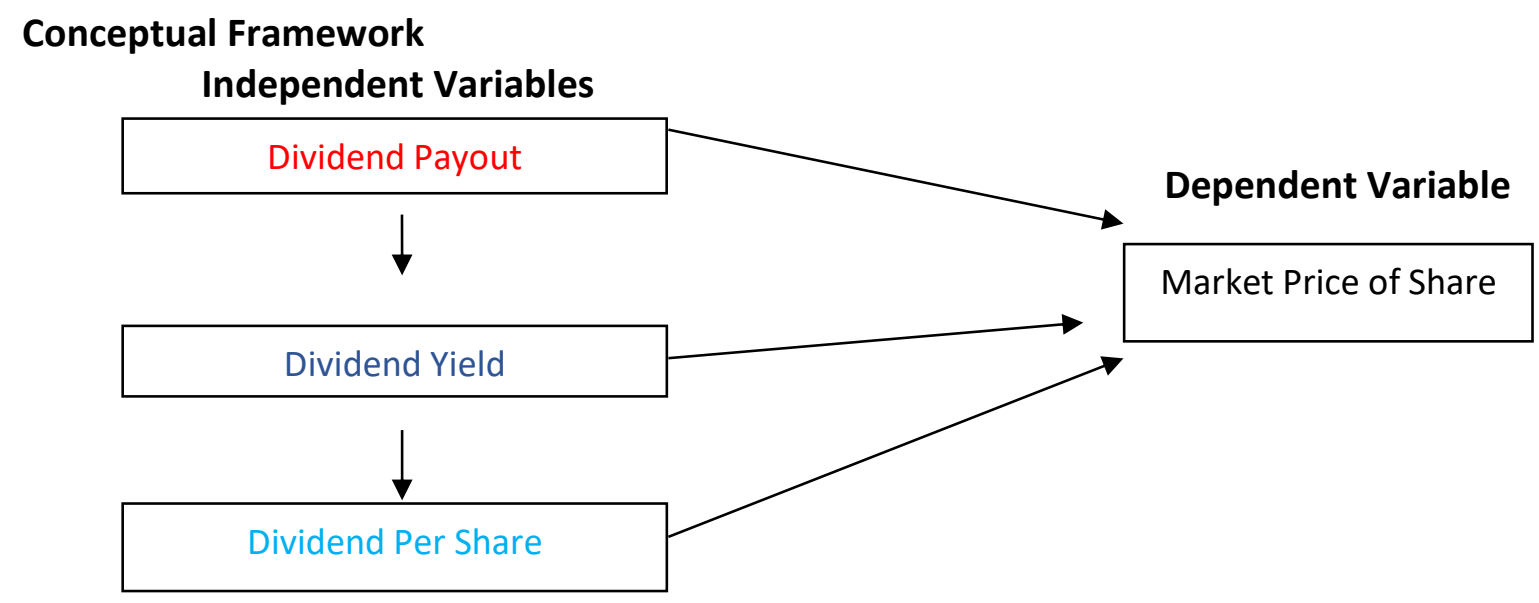

Source: Researcher's Concept (2021)

\section{Theoretical Framework}

This work is anchored on two theories. The Signaling Hypothesis Theory and The Gordon/Lintner Bird in the Hand Theory. It assumes both knowledge and acceptance of these theories that this research work depends upon.

\section{The Signaling Hypothesis Theory}

The Signalling Hypothesis Theory was propounded by Michael Spencer in the year 1973 which centered on observed knowledge gaps between organizations, investors and employees. Such knowledge gap affects decision like a situation where current stock price is lower than the value signals that management will not issue new equities to the market. The theory revealed that information asymmetry between managers and outside shareholders allows managers to use dividends as a tool to signal private information about a firm's market performance to outsiders. Signalling theory posits that dividend policy would be considered as a mechanism to transfer information about a company's future expectation to the investor.

According to the theory, cash dividend announcements convey valuable information, which shareholders do not have, about management's assessment of a firm's future profitability thus reducing information asymmetry. Such information can be made use of by investors in assessing the firm's share price and making investment decisions. Therefore, investors can use this information to estimate the share value of a company. Dividend policy under this model is therefore considered relevant.

\section{The Gordon / Lintner (Bird-in-the-Hand) Theory}

The bird-in-the-hand theory was hypothesized independently by Lintner in the year 1962 and Gordon in the year 1963. The theory states that dividends are relevant in determining the value of the firm. In a popular common stock valuation model developed by Gordon, the determinants of the value of a firm's cost of equity financing are the dividends the firm is expected to pay to perpetuity, the expected annual growth rate of dividends and the firm's current stock price. The dividend yield and the future growth of the dividends provide the total return to the equity investor.

This theory insists that dividend yield is a more important measure of the total return to the equity investor than the future growth rate of the dividends (which is the rate at which the net earnings and the capital gains of the firm will grow at in the future). Future growth, and hence capital gains cannot be estimated with accuracy and are not guaranteed at all as firms 
might lose even their entire market value in the stock exchange and go bankrupt. If a firm does not pay dividends therefore, its forward looking market value is severely affected by the uncertainty surrounding the possibility of the investors' ever booking the capital gains. Dividend policy under this model is also considered relevant.

\section{Empirical Literature}

\section{Dividend Payout and Share Price of Firms}

Al- Hasan, Asaduzzaman, and Karim (2013) were of the opinion that the most debated issue in the field of finance is over the effect of dividend policy on market price per share. Their study aimed at evaluating the effect of dividend policy on market price of shares in the context of Bangladesh. The study covered secondary data and analyzed the data by employing descriptive statistics, correlation and multiple regression models. It tested hypothesis using $\mathrm{F}$ test. The study found that the effect of dividend payout is more on market price than retention. Uwuigbe, Jafaru, and Ajayi (2012) investigated the relationship between the financial performance and dividend payout among listed firms' in Nigeria for the period 20062010 using the regression analysis method. The study found significant and positive association between the performance of firms and dividend payout. The study also revealed that ownership structure and firm's size has a significant impact on dividend payout of firms. Aivazian, and Cleary (2013) maintained that firms are more likely to raise their dividends if they are large and profitable. Their studies proved that the profitability is positively related to the dividend payout ratio. Profitable firms with more stable net earnings can afford larger free cash flows and therefore pay larger dividends. Velnampy, Nimalthasan and Kalaiarasi (2014) noted that dividend policy measures are not significantly correlated with dividend payout as dividend policy and earnings per share, return on equity and return on assets as firm performance measures. Enekwe, Nweze and Agu (2015) reported that dividend payout ratio (D.P.R) has positive and significant relationship with Return on Asset (R.O.A) and Return on Capital Employed (ROCE) while DPR is statistically insignificant with Return on Equity (ROE) of quoted cement companies in Nigeria.

Kanwal and Shashid (2017) in their study noted that dividend payout positively influenced financial performance of firm. It was also noted that the firm financial performance is influenced by the dividend policy. Using regression model, the study concludes that dividend payout has effect on firms performance. Ebire (2018) on effect of dividend policy on the performance of listed oil and gas firms in Nigeria explored the statistical test tool of OLS model and found that dividend payout ratio positively impact earnings per share of listed oil and gas firms in Nigeria

\section{Dividend Yield and Share Price of Firms}

Ordu, Enekwe and Anyanwaokoro (2014) suggested that dividend yield does not have a significant positive effect on the market prices of shares of quoted firms in Nigeria using the empirical results arising from the panel least squares. Ball, Brown, Finn (1979) studied the relationship between dividends and stock price in Australian stock market. The study found significant relationship between stock prices and dividend yield in the next year after dividend payment. Hussainey, Mgbame and Chijoke-Mgbame (2011) found positive relation between dividend yield and stock price using ordinary least square. The study concludes that dividend yield exert significant effect on firms stock prices

Ebire (2018) on effect of dividend policy on the performance of listed oil and gas firms in Nigeria explored the statistical test tool of OLS model and found that dividend yield has a 
significant but negative effect on earnings per share. Based on this, the study therefore recommends that oil and gas firms willing to maximize shareholders wealth should pay higher dividends. Magnusson and Enebrand (2018) results show that the stock price of high dividend yields firms is more dependent on financial performance compared to low dividend yield firms. However, an overall positive correlation is found between stock price and financial performance using regression model.

\section{Dividend Per Share and Share Price of Firms}

Empirical findings by Ordu, Enekwe and Anyanwaokoro (2014) using time series analysis showed a positive effect between market price per share and dividend per share confirming that a rise in dividend per share brings about an increase in the market price per share of quoted firms. In Nigeria, Adelegan (2009) researched into the price reactions to dividend announcements in the Nigerian Stock Market and concludes that dividend policy matters and that share prices do react to dividend announcements.

Kouki and Guizani (2019) also observed in their study using regression model that managerial ownership appears to have a visible and significant effect on dividend per share. Kumar (2016) on the same vein posits that dividend per share has significant and positive relation with firms share price. The study used OLS and concluded that firms' dividend per share influences market price of shares.

Nduta (2016) studied on effect dividend policy on financial performance of firms listed on Nairobi Securities Exchange and found out that the major factors that affect financial performance of listed firms are timing of dividend payments and dividend payments. Other factors for example leverage and total assets have no significant effect on the financial performance of a firm.

\section{Methodology}

This study adopts Ex-Post Facto Design. This was adopted based on the fact that our data is secondary data that exists already which cannot be manipulated or controlled. The population of the study consists of the entire 9 firms quoted under ICT Sector of NSE as at 2021 business list covering from 2016-2020. The use of quoted ICT companies on NSE could be justified based on availability and reliability of their financial data. Out of 9 firms that formed our sample size, 3 firms have empty financial information within the period under study (Airtel Africa Plc, Omatek Ventures PIc and MTN Nigeria Comm PIc) which was removed. Based on this, a total of 6 firms formed our sample size with 30 observations.

The study used data from secondary sources which are quantitative in nature. The data were obtained from the NSE Factbook. OLS Model was employed to examine the impact of dividend policy (DPO, DY \& DPS) on firms' share price represented by Market Price of Shares (MPS). Data was analyzed using STATA 15. Various robustness tests such as Variance Inflation Factor (VIF), Tolerance Value (TV), Ramsey Reset Test (RRT), Breusch Pagan/Cook Weisberg Heteroskedasticity (HT) were explored in order to determine if there is a multi-colinearity existence or auto correlation of the regressors.

\section{Operationalization and Measurement of Variables Dependent Variable}

The dependent variable in this study is Share Price and was represented by Market Price of Shares (MPS). 


\section{Independent Variable}

Independent variables were captured using Dividend Payout (DPO), Dividend Yield (DY) and Dividend Per Share (DPS)

\section{Measurement for Independent Variable}

\begin{tabular}{|l|l|l|}
\hline Variable & Measurement & A priori Expectations \\
\hline Dividend Payout & DPS/EPS & $\begin{array}{l}\text { Al- Hasan, Asaduzzaman, and Karim (2013), Uwuigbe, } \\
\text { Jafaru and Ajayi (2012) }\end{array}$ \\
\hline Dividend Yield & DPS/MPS & $\begin{array}{l}\text { Ordu, Enekwe and Anyanwaokoro (2014), Ebire } \\
(2018)\end{array}$ \\
\hline Dividend Per Share & $\begin{array}{l}\text { DD/No of } \\
\text { Common Stock }\end{array}$ & $\begin{array}{l}\text { Ordu, Enekwe and Anyanwaokoro (2014), Nduta } \\
(2016)\end{array}$ \\
\hline
\end{tabular}

Source: Empirical Survey (2021).

\section{Model Specification and Justification}

The study adapted and modified the model of Abdul (2018) as shown below;

Abdul (2018): ROE $=\beta_{0}+\beta_{1} D P S+\beta_{2} E P S+\beta_{3} F S+\beta_{4} F L+\mu$

The modified model for the study is shown as thus:

$\mathrm{MPS}_{\mathrm{t}}=\beta_{0}+\beta_{1} \mathrm{DPO}_{\mathrm{t}}+\beta_{2} \mathrm{DY} Y_{\mathrm{t}}+\beta_{3} \mathrm{DPS}_{\mathrm{t}}+\mu$

Where

ROE = Return on Equity

EPS $=$ Earnings Per Share

$\mathrm{FS}=$ Firm Size

$\mathrm{FL}=$ Financial Leverage

MPS $=$ Market Price of Shares

DPO = Dividend Payout

DY $=$ Dividend Yield

DPS = Dividend Per Share

$\mu=$ error term

\section{Data Analysis and Results}

Variance Inflation Factor (VIF), Tolerance Value (TV), Breusch Pagan and Cook-Weisberg Heteroskedasticity Test, Ramsey Reset Test (RRT) were explored for test of multi-collinearity existence and auto correlation of the regressors. OLS Model on the hand was used to test the linear relationship between the dependent and independent variables. It was operated using STATA version 15 as shown on the tables below:

Table 1: Collinearity Statistics

. estat vif

\begin{tabular}{|c|c|c|}
\hline Variable & | & 1/VIF \\
\hline DPO | & 1.08 & 0.927673 \\
\hline DPS I & 1.04 & 0.959395 \\
\hline DY I & 1.04 & 0.964545 \\
\hline
\end{tabular}


From the table above, the TV ranges from 0.927 to 0.964 which suggests non multi-collinearity feature. The VIF which is simply the reciprocal of TV ranges from 1.08 to 1.04 also indicates non multi-collinearity feature.

\section{Table 2: Breusch Pagan/Cook Weisberg Heteroskedasticity for the Model} . estat hettest

Breusch-Pagan / Cook-Weisberg test for heteroskedasticity

Ho: Constant variance

Variables: fitted values of MPS

$\operatorname{chi} 2(1)=0.66$

Prob $>$ chi2 $=0.4167$

The above result was obtained from the test for heteroskedasticity. The probability value of 0.4167 resulting from the test for heteroskedasticity implies that the model is free from the presence of unequal variance. Thus implies that our probability values for drawing inference on the level of significance are reliable and valid. The absence of heteroskedasticity validates the regression model results, which means there is no need for robust or weighted least square regression.

\section{Table 3: Ramsey Reset Test for the Model}

\section{. estat ovtest}

Ramsey RESET test using powers of the fitted values of MPS

Ho: model has no omitted variables

$$
\begin{array}{ll}
F(3,23)= & 4.06 \\
\text { Prob }>F= & 0.9798
\end{array}
$$

The above result was obtained from the test for miss-specification or omitted variables using Ramsey RESET Test. The probability value of 0.9798 resulting from the test implies that the model has no omitted variables.

\begin{tabular}{|c|c|c|}
\hline Source | & SS $\quad d f$ & MS \\
\hline Model | & 7.81549172 & 32.60516391 \\
\hline Residual | & 128.351175 & 264.93658365 \\
\hline
\end{tabular}

Table 4: Result on Impact of Dividend Policy on Share Price of ICT Firms in Nigeria.

Number of obs $=30$

$$
\begin{aligned}
& F(3,26)=0.53 \\
& \text { Prob }>F=0.0072 \\
& \text { R-squared }=0.5704
\end{aligned}
$$

Adj R-squared $=0.4514$

Root MSE $=0.2218$

\begin{tabular}{ccccccc} 
MPS | Coef. Std. Err. $t$ & $\mathrm{P}>|\mathrm{t}|$ & {$[95 \%$} & Conf. Interval] \\
\hline$-\mathrm{yPO} \mid .2877601$ & .4576938 & 2.63 & 0.005 & 1.228563 & .65304290 \\
DP | 2405184 & .3776409 & 3.64 & 0.000 & 1.016770 & .53573370 \\
DPS | .4329018 & .6779514 & 4.64 & 0.002 & .9606472 & 1.8264510 \\
_cons | 2.352280 & .7838320 & 3.00 & 0.001 & .7410904 & 3.963470
\end{tabular}

Source: Result output from STATA 15. 


\section{Discussion of Findings}

The result of the analysis of the study using OLS Model is expressed as follows:

$\mathrm{H}_{01}$ : Dividend Payout has no significant Impact on Share Price of Listed ICT Firms in Nigeria. In view of the above analysis as shown on table 4, the result shows that there is a significant and positive relationship between dividend payout and share price of listed ICT firms in Nigeria. With a P-value of 0.005 , the test is considered statistically significant at $1 \%$ level. This could be verified with the coefficient of correlation of $28.7 \%$ which indicates that an increase in firms dividend payout as other variables are been held constant increases market price of shares by $28.7 \%$. Based on this, we rejected the null hypothesis and accepted alternate hypothesis which contends that dividend payout has significant impact on market price of shares. This agrees with the a priori expectations of Ebire (2018) on effect of dividend policy on the performance of listed oil and gas firms in Nigeria. The study found that retained earnings and dividend payout ratio positively impact earnings per share of listed oil and gas firms in Nigeria. Also Kanwal and Shashid (2017) in his study noted that dividend payout positively influenced financial performance of firm. The finding of this study is also in consonance with the study of Enekwe, Nweze and Agu (2015) who reported that dividend payout ratio has positive and significant relationship with Return on Asset and Return on Capital Employed.

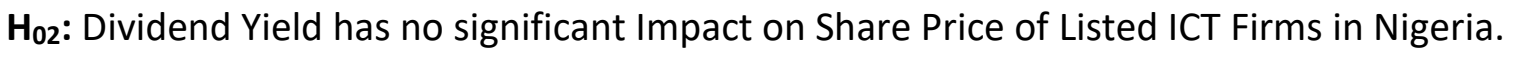
In view of the above analysis as shown on table 4, the result shows that there is a significant and positive relationship between dividend yield and share price of listed ICT firms in Nigeria. With a P-value of 0.000 , the test is considered statistically significant at $1 \%$ level. This could be verified with the coefficient of correlation of $24.1 \%$ which indicates that increase in firms dividend payout as other variables are been held constant increases market price of shares by $24.1 \%$. Based on this, we rejected the null hypothesis and accepted alternate hypothesis which contends that dividend yield has significant impact on market price of shares. This is not in tandem with the study carried out by Ordu, Enekwe and Anyanwaokoro (2014). The study suggested that dividend yield does not have a positive and significant relationship with the market prices of shares of quoted firms in Nigeria using the empirical results arising from the panel least squares. On the contrary, Hussainey, Mgbame and Chijoke-Mgbame (2011), Ebire (2018) and Ball, Brown, Finn and Officer, (1979) found positive relation between dividend yield and stock price.

$\mathbf{H}_{03}$ : Dividend Per Share has no significant impact on Share Price of Listed ICT Firms in Nigeria. In view of the above analysis as shown on table 4, the result shows that there is a significant and positive relationship between dividend per share and share price of listed ICT firms in Nigeria. With a P-value of 0.002 , the test is considered statistically significant at $1 \%$ level. This could be verified with the coefficient of correlation of $43.3 \%$ which indicates that increase in firms dividend payout as other variables are been held constant increases market price of shares by $43.3 \%$. Based on this, we rejected the null hypothesis and accepted alternate hypothesis which contends that dividend per share has significant impact on market price of shares. This agrees with the a priori expectations of Ordu, Enekwe and Anyanwaokoro (2014), Nduta (2016) who reported that dividend per share and the market value of share prices have significant and positive relationship.

\section{Conclusion}

The study from the statistical analysis concludes that dividend policy has significant impact on market price of shares of firms in Nigeria. 


\section{Recommendation}

Based on findings of the study, the following recommendations are made:

1. Management should adopt good dividend payout policies in order to reduce agency cost and maximise the value of the company which attracts more investors.

2. Management should design a dividend policy that would benefit the shareholders and enhance market price of shares. Once investors don't get the value of their investment, they tend to divert their funds to other investment opportunities that could yield them immediate returns.

3. A stable policy should be decided for declaration and payment of dividend constantly. The total income of the current year should not be distributed among the shareholders as a dividend or to retain total income as a free cash flow, as this will discourage investors.

\section{Contribution to Knowledge}

i. The study adapted and modified the model of Abdul (2018) as shown below;

Abdul (2018): ROE $=\beta_{0}+\beta_{1} D P S+\beta_{2} E P S+\beta_{3} F S+\beta_{4} F L+\mu$

The modified model for the study is shown as thus:

$M P S_{t}=\beta_{0}+\beta_{1} D P O_{t}+\beta_{2} D Y_{t}+\beta_{3} D P S_{t}+\mu$

The study contributed to knowledge by revealing that:

MPS $_{t}=\beta 0+\beta_{1} \operatorname{DPO}_{t}(0.28\{0.005\})+\beta_{2} \operatorname{DY}_{t}(0.24\{0.000\})+\beta_{3} \operatorname{DPS}_{t}(0.43\{0.002\})+\mu$

By this implication, the study asserts that the overall model is statistically significant. The variables (DPO, DY \& DPS) have significant effect on the dependent variable (MPS).

ii. The study also contributed to knowledge through the conceptual model developed and designed for the study. It is shown below as;

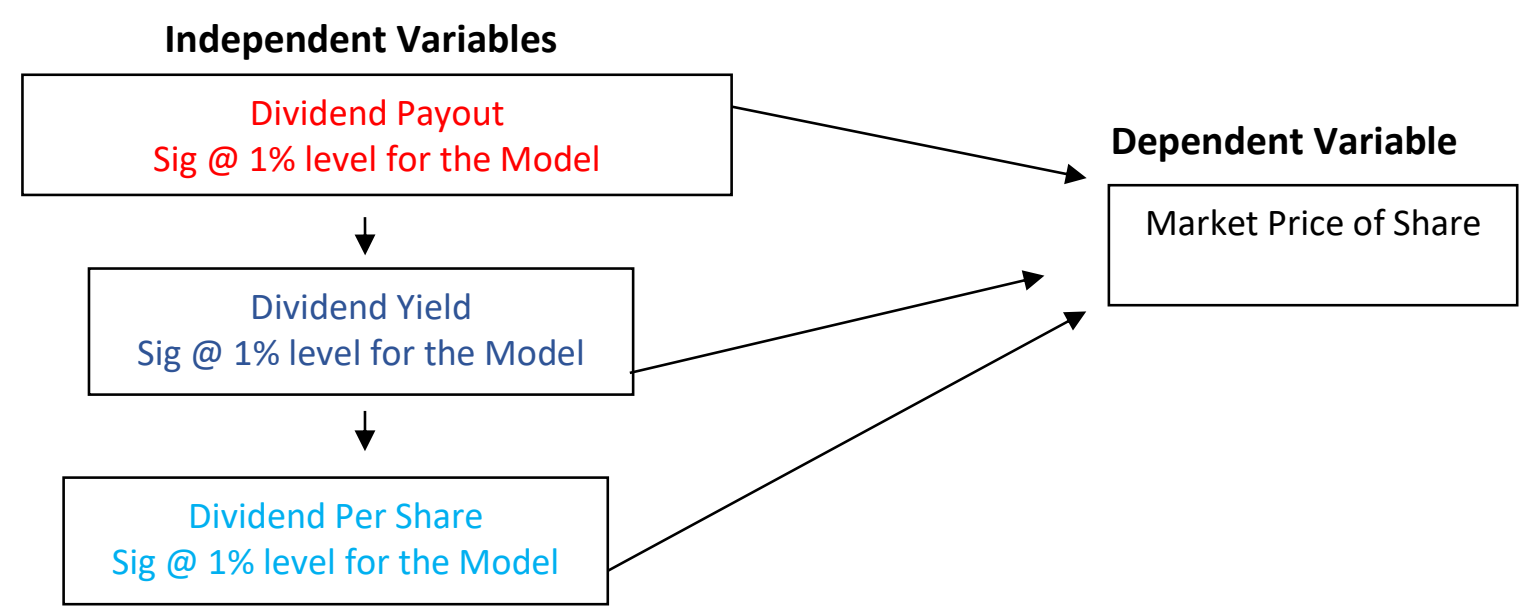

Source: Researcher's Concept (2021)

\section{References}

Abdur, R. (2018). Effect of dividend policy on firms performance: a case study of cement sector of Pakistan. SEISENSE Journal of Management, 1(5), 6-15

Adelegan, O. (2009). Price reactions to dividend policy changes on the Nigerian stock market. African Journal of Economic Policy, 13(2), 23-45

Aivazian, V., Booth, L., \& Cleary, S. (2013). Do emerging market firms follow different dividend policies from US firms? Journal of Financial Research, 26(3), 371-387 
Al- Hasan, M. A., Asaduzzaman, M., \& Al Karim, R. (2013). The effect of dividend policy on share price: An evaluative study. IOSR Journal of Economics and Finance, 1(4), 6 -11

Ball, R., Brown, P., \& Finn, F. (1979). Dividends and the value of the firms, Australian Journal of Management, 4, 13-26

Ebire, M., \& Onmonya, L. (2018). Effect of dividend policy on the performance of listed oil and gas firms in Nigeria. International Journal of Scientific and Research Publications (IJSRP), 8(6)

Ejuvbekpokpo, A., \& Okoro, S. (2014). Determinants of stock price movement in Nigeria: evidence from the Nigerian stock exchange. Journal of Economics and Sustainable Development, 5(3), 1-7

Enekwe, C. I., Nweze, A. U., \& Agu, C. (2015). The effect of dividend payout on performance evaluation: Evidence of quoted cement companies in Nigeria. European Journal of Accounting, Auditing and Finance Research, 3(11), 40-59.

Gordon, M. J. (1963). Optimal investment and financing policy. The Journal of finance, 18(2), 264-272

Hussainey, K., Mgbame, C., \& Chijoke-Mgbame, A. M. (2011). Dividend policy and share price volatility: UK evidence. The Journal of risk finance, 12(1), 57-68

Kanwal, M., \& Shahid, H. (2017). The Relationship between Dividend Payout And Firm Financial Performance. Research in Business and Management, 4(1), 5-13.

Kouki, M., \& Guizani, M. (2019). Ownership structure and dividend policy evidence from the Tunisian Stock Market. European Journal of Scientific Research, 25(1), 42-53

Kumar, J. (2016). Corporate governance and dividend policy in India. Journal of Emerging Market Finance, 5(5), 15-58

Lintner, J. (1962). Dividends, earnings, leverage, stock prices and supply of capital to corporations. The Review of Economics and Statistics, 44, 243-269.

Magnusson, T., \& Enebrand, A. (2018). Dividend policy and its impact on firm valuation: A study of the relationship between dividend policy and stock prices on the Swedish market.

Malhotra, N., \& Tandon, K. (2013). Determinants of stock prices: empirical evidence from NSE 100 companies, IRACST-International Journal of Research in Management and Technology (IJRMT), 3(3).

Nduta, N. (2016). The effect of dividend policy on the financial performance of firms listed at the Nairobi securities exchange. Master Theses - College of Humanities and Social Sciences.

Nissim, D., \& Ziv, D. (2011) "Dividend changes and future profitability", Journal of Finance, 56 (6), 2111-2133

Ogbuagu, N. (2020). Effect of dividend policy on firms performance. Journal of Accounting, Business and Social Sciences, 3(2), 1-18

Olimalade, A., \& Adewumi, W. (2017). Business finance; issues and topics, Nigeria: Nigerian Education Publication.

Omaliko, E., \& Okpala, N. (2020). Effect of environmental disclosures on dividend payout of firms in Nigeria, International Journal of Banking and Finance Research, 6(3), 14-28

Omaliko, E., Nweze, A., \& Nwadialor, E. (2020). Effect of social and environmental disclosures on performance of non-financial firms in Nigeria, Journal of Accounting and Financial Management, 6(1), 40-58

Omaliko, E., \& Okpala, N. (2020). Effect of TSA on solvency of listed deposit money banks in Nigeria. World Journal of Finance and Investment Research, 5(1), 32-47 
Omaliko, E., Okeke, P., \& Obiora, F. (2021). Impact of covid-19 pandemic on liquidity and profitability of firms in Nigeria, International Journal of Academic Research in Business and Social Sciences, 11(3), 1331-1344

Okafor, C., Mgbame, C., \& Chijioke-Mgbame, A. (2011). Dividend policy and share price volatility in Nigeria. JORIND Publications, 9(1), 55-65

Ordu, M., Enekwe, C., \& Anyanwaokoro, M. (2014). Effect of dividend payment on the market price of shares: a study of quoted firms in Nigeria. IOSR Journal of Economics and Finance, 5(4), 49-62

Rehman, O. (2016). Impact of capital structure and dividend policy on firm value. Journal of Poverty, Investment and Development, 21(1), 40-57

Sorin, A. (2016). The impact of dividend policy on firms value. Journal of Public administration, Finance and Law, 10, 107-112

Spencer, M. (1973). Signaling theory: a review and assessment. The Quarterly Journal of Economics, 87(3), 355-374

Uwuigbe, U., Jafaru, J., \& Ajayi, A. (2012). Dividend policy and firm performance: a study of listed firms in Nigeria. Accounting and Management Information Systems, 11(3), 442454

Velnampy, T., Nimalthasan, M. P., \& Kalaiarasi, M. K. (2014). Dividend policy and firm performance: Evidence from the manufacturing companies listed on the Colombo stock exchange. Global Journal of Management and Business Research, 14(6), 2-8 